\title{
New directions in hydro-climatic histories: observational data recovery, proxy records and the atmospheric circulation reconstructions over the earth (ACRE) initiative in Southeast Asia
}

\author{
Fiona Williamson ${ }^{1 *}$, Rob Allan², Adam D Switzer ${ }^{3}$, Johnny C L Chan ${ }^{4}$, Robert James Wasson ${ }^{5}$,
} Rosanne D'Arrigo ${ }^{6}$ and Richard Gartner ${ }^{7}$

\begin{abstract}
The value of historic observational weather data for reconstructing long-term climate patterns and the detailed analysis of extreme weather events has long been recognized (Le Roy Ladurie, 1972; Lamb, 1977). In some regions however, observational data has not been kept regularly over time, or its preservation and archiving has not been considered a priority by governmental agencies. This has been a particular problem in Southeast Asia where there has been no systematic country-by-country method of keeping or preserving such data, the keeping of data only reaches back a few decades, or where instability has threatened the survival of historic records. As a result, past observational data are fragmentary, scattered, or even absent altogether. The further we go back in time, the more obvious the gaps. Observational data can be complimented however by historical documentary or proxy records of extreme events such as floods, droughts and other climatic anomalies. This review article highlights recent initiatives in sourcing, recovering, and preserving historical weather data and the potential for integrating the same with proxy (and other) records. In so doing, it focuses on regional initiatives for data research and recovery - particularly the work of the international Atmospheric Circulation Reconstructions over the Earth's (ACRE) Southeast Asian regional arm (ACRE SEA) - and the latter's role in bringing together disparate, but interrelated, projects working within this region. The overarching goal of the ACRE SEA initiative is to connect regional efforts and to build capacity within Southeast Asian institutions, agencies and National Meteorological and Hydrological Services (NMHS) to improve and extend historical instrumental, documentary and proxy databases of Southeast Asian hydroclimate, in order to contribute to the generation of high-quality, high-resolution historical hydroclimatic reconstructions (reanalyses) and, to build linkages with humanities researchers working on issues in environmental and climatic history in the region. Thus, this article also highlights the inherent value of multi/cross/inter-disciplinary projects in providing better syntheses and understanding of human and environmental/climatic variability and change.
\end{abstract}

Keywords: Southeast Asia; Climate; Instrumental observational and documentary data; Reanalyses; Hydroclimatic proxies; History

\footnotetext{
* Correspondence: f.williamson@uea.ac.uk

${ }^{1}$ School of History, Politics and Strategy, Faculty of Social Sciences and

Humanities, National University of Malaysia, Selangor 43600, Malaysia

Full list of author information is available at the end of the article
} 


\section{Introduction}

ACRE Southeast Asia (ACRE SEA) is part of the global Atmospheric Circulation Reconstructions over the Earth (ACRE) initiative [3] run from the Met Office Hadley Centre $(\mathrm{MOHC})$ in the UK. ${ }^{\mathrm{a}}$

ACRE seamlessly links together three components:

- historical instrumental global surface terrestrial and marine weather data recovery, imaging, digitisation and quality control

- feeding these data into major international repositories (International Comprehensive Ocean Atmosphere Data Set [ICOADS] and the International Surface Pressure Databank [ISPD]), which provide the best quality and quantity of surface weather observations for assimilation into all dynamical weather reconstructions (reanalyses) ${ }^{\mathrm{b}}$.

- ensuring that reanalyses outputs are freely available and feed smoothly into the climate science, climate applications, impacts, risks and extremes communities

Importantly, the initiative works very closely with NMHS and various weather and climate data rescue initiatives such as the International Environmental Data Rescue Organisation (IEDRO), the International Surface Temperature Initiative (ISTI), the Global Precipitation Climatology Centre (GPCC), the National Climatic Data Center (NCDC), the Climatic Research Unit (CRU) and others to ensure that all of the variables recovered and digitised are fed back to their points of origin and/or to the appropriate international repositories responsible for that data. It also encourages, where possible, NMHS and other international initiatives to aid in data quality control and the full rehabilitation of such observations. Further support in ratifying such actions is being sought with WMO via their Commission for Climatology's Expert Team on Data Rescue (ETDARE). In addition, any other historical meteorological, hydrological or oceanographic variables uncovered by ACRE are brought to the attention of the relevant communities working on them, such as the EU FP7 European Reananlysis of the Global Climate System (ERA-CLIM2) project with upper air data (http://www.era-clim.eu/) [4] and the Global Sea Level Observing System (GLOSS) (http://www.gloss-sealevel. org/data/glossdataarchaeology.html\#.VGm8SfHYOtg).

ACRE is also unique in that it is now working across many disciplines to better facilitate historic data (documentary and proxy) recovery. The initiative embraces research based on proxies of hydroclimatic extremes such as flood sediments in fluvial and coastal archives but the value of integrating historic research with data recovery efforts has also become increasingly apparent in ACRE's broad quest to recover historic weather observations. As a result, ACRE has been particularly active in looking to work with disciplines outside of climate science. In the UK, it has been a member of, and/or contracted by, various social sciences, humanities and arts projects funded outside of the mainstream science sources. It is now looking to be a catalyst in efforts to meld together climate science, historical reanalyses, social sciences and humanities studies of climatic variability and change. ACRE SEA has been a part of this drive, participating in the University of Sussex' Centre for World Environmental History's UK Arts and Humanities Council (AHRC) funded network project 'Botanical and Meteorological History of the Indian Ocean, 1600-1900' and King's College London's and Aberystwyth University's AHRC funded network projects 'Historic Weather' and 'Historic Weather2'.

By working with these, and other similar projects, it is hoped that recovered data (post imaging and digitisation) can be utilised by a wide academic community and even the general public. The supporting premise is that data rarely exist alone, but are found in context with their historic source. The English East India Company (EEIC) ship logbooks, for example, which contain excellent weather observations from at least the $1780 \mathrm{~s}$, are also full of narratives of a vessel's several year voyage and include detailed descriptions of the crew and their lives aboard ship, as well as the lands to which they travelled. Likewise, weather observations taken in Southeast Asia and India were often compiled by colonial surgeons and doctors investigating the relationship between tropical climates and disease. Such records are invaluable for historians and social scientists as well as climate scientists and, by working together, knowledge of surviving data can be shared and improved.

ACRE also aims to extend its impact beyond the academic community by engaging the general public in the process and results of data recovery. By working with online initiatives aimed at digitizing historic records including Old Weather (http://www.oldweather.org) or Weather Detective (http://www.weatherdetective.net.au), ACRE has been able to communicate and share the valuable results of its collaborative research, especially documentary evidence, with the public.

ACRE has a global focus and this has led to the development of various regional foci, covering Chile, the Pacific, China, Meso-America, the Indian Ocean, Africa, and Antarctica all of which are at various stages of development. The Southeast Asian regional focus is one of the more recent foci, and has been operating officially since 2013, on receipt of funding from the Asia-Pacific Network for Global Change Research's (http://www.apn-gcr.org) CAPaBLE scheme for 2013-15. ACRE SEA's primary goal is to build capacity within Southeast Asian NMHS to 
improve and extend historical instrumental, documentary and proxy databases of Southeast Asian weather and climate, in order to contribute to the generation of high-quality, high-resolution historical hydroclimatic reconstructions. It aims to do this by researching surviving historical instrumental and documentary data, by motivating and undertaking proxy-based research, and by co-ordinating with owner institutions to preserve, image and, where appropriate, digitize, these data. Ultimately, the aim is to make all of this material available for reanalyses, and facilitate the melding of these results with documentary evidence and proxy-based reconstructions to increase the time span of reliable data (see Figure 1).

The resultant new baselines generated by this approach will allow scientists, academics and policy makers across the region to analyse and address weather and climate extremes, impacts and risks in ways and over time spans not previously possible [5]. However, recovered data does not only have significance for reanalysis. Data recovery efforts must be closely linked with the work of NHMS and other interested organisations to ensure that raw data is rendered both comprehensible and usable for a broad audience, especially the various stakeholders, for example, policy makers, the academic community, and the public.

The remainder of this article will consider the historic background to meteorological research in Southeast Asia; explore the current state of historical observational and documentary data recovery in the region, including the work of ACRE SEA and key regional projects and multi-disciplinary research in the field; provide examples of the use and potential in assessing proxy-based reconstructions; and finally, will consider problems encountered and suggest ways forward for the future.

\section{Review}

Historic meteorological observations: context and sources Narrative accounts of the weather survive globally from time-out-of-mind, but the practice of regular and meticulous instrumental weather observation dates back only as far as technological advances in accurate instrument making allow, namely the eighteenth and nineteenth centuries. As in most parts of the world, the most obvious places to look for historical instrumental observations and documentary evidence of past weather and climate from this period are in the libraries and archives of various bodies including NMHS, the military, or national government administrations. Observations are found in many documentary sources, including old books, periodicals and journals, ship logbooks, in experimental medical and scientific research, military reports and records, newspapers, and diaries. Doctors working for colonial administrations in Southeast Asia, for example, made note of precipitation and temperature in tropical and monsoonal environments in order to understand connections between climate and disease. Meteorological observations have historically been made at a variety of places: on board naval and commercial shipping vessels, at magnetic observatories, lighthouses, ports, hospitals, and aerodromes, to name but a few. Observations could be fixed to short periods of time, for example, kite/ balloon/aircraft meteorograph experiments, or be routine and long-term taken over many years at fixed observatories and stations. Some observations remain in private hands - in personal correspondence or diaries - while others have been retained and preserved by public institutions. As many countries in Asia made the transgression from colonial possessions to independent nations, this added another layer of complexity, in that material could well be held in combinations of various

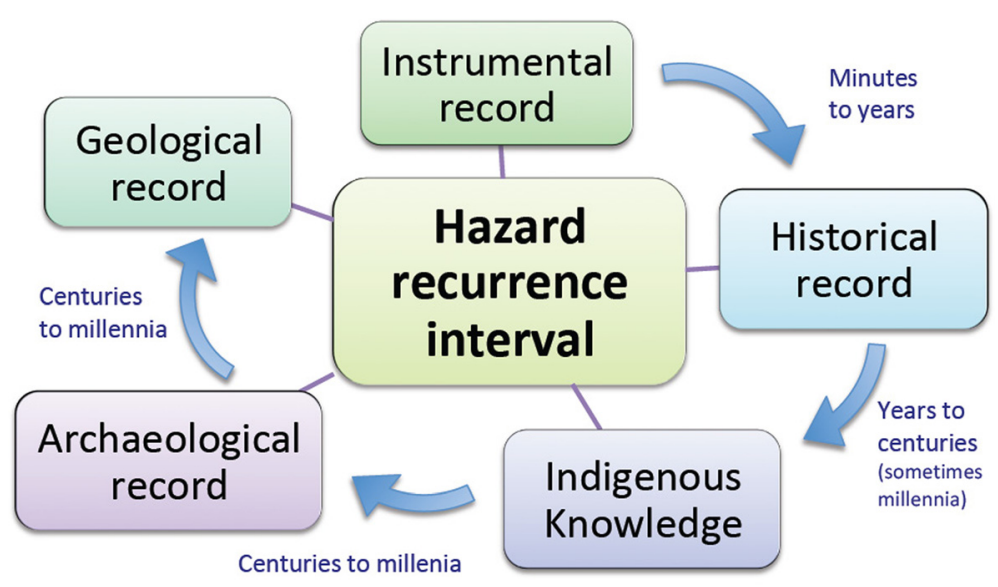

Figure 1 Summary diagram of the integrated approach to the analysis of hazards from different records and archives of differing timeframes. A similar approach can be applied to other hazards, such as tsunamis or volcanic eruptions (modified from [12]). 
national repositories of the old European powers, as well as the libraries, museums and archives of contemporary states. Rarely, it seems, are all old weather observations kept in one repository.

In most cases, recorded observations were made on a pre-formatted sheet or logbook. Globally, these tend to follow a set pattern from the nineteenth century onwards, recording temperature of the air (wet and dry bulb), pressure and precipitation in tandem, often in conjunction with other qualifying information, for example, a description of the clouds, or state of the sea depending on the context (see Figure 2).

One important example of marine weather observations made across parts of the tropical and sub-tropical ocean regions of the globe are the four thousand or so logbooks of EEIC vessels that sailed between England, Asia, and Southeast Asia across the Atlantic and Indian Oceans from the early 1600s (https://sites.google.com/a/ oldweather.org/www/examples/east-india-company).

Each ship was obliged to keep a logbook, compiled daily by the captain or master who would record detailed descriptions of the weather encountered during the voyage. In addition, one should not forget the Dutch, Portuguese and Spanish ship logbooks, as their vessels continued to sail to their colonies long after the dominance of their empires that ruled them had faded. ${ }^{\mathrm{c}}$ From the 1790s, barometer and thermometer readings were entered as standard practice in English logbooks. The making and recording of accurate sub-daily observations had become a routine part of the Company captain's role, largely thanks to the efforts of hydrographers such as James Horsburgh with the EEIC and Alexander Dalrymple [6], the first official Royal Navy Hydrographer, who insisted that all vessels carry observational instruments and that observations should be standardized.

Alexander Dalrymple was not the only influential figure to recognize the importance of keeping accurate observational logs at sea however. In the nineteenth century, Royal Society member and astronomer John Herschel argued the importance of military discipline as essential training for officers keeping accurate subdaily readings [7]. European scientists played critical roles in improving data reliability and standardisation. Adolphe Quetelet, director of the Royal Observatory in Brussels from 1828, wrote extensively on statistical methodology for meteorology at around the same time as John Frederic Daniell, Alexander von Humboldt and Heinrich Dove were arguing the value of accurate, regular observations and the making of extended sets of observational averages covering wide time scales [8]. Under the guidance of such influential men, the $1800 \mathrm{~s}$ marked a watershed in the keeping of regular instrumental observations on land, as well as at sea. In 1839, for example, British Colonial secretary Lord Glenelg issued an order to all administrators across the British Empire to keep records of the 'state of the weather' across all the colonies - this included port and harbour masters, lighthouse keepers, or 'other public functionaries'. ${ }^{\mathrm{d}}$ It was after this (in Britain at least) that regular records of the weather were kept and included in the annual reports colonial governors sent to the British administration in India, or to the government in London. At around the same time, members of The British Association for the Advancement of Science

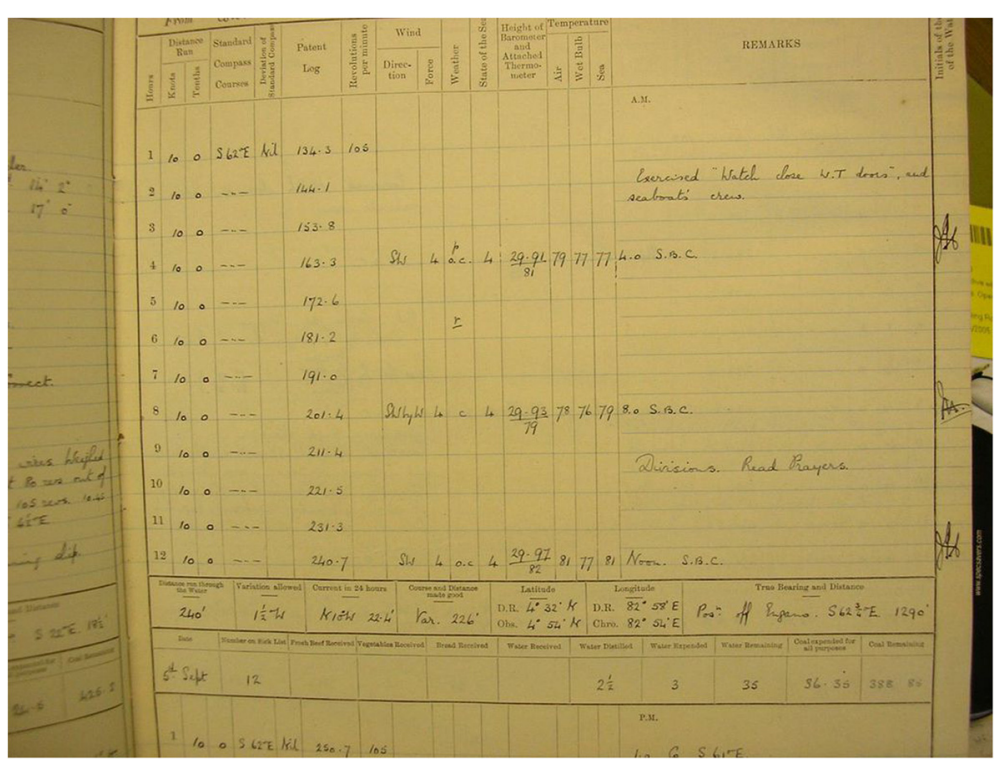

Figure 2 Example of weather observations from the 1909 voyage logbook of the HMS Pyramus, image courtesy of the national archives, Kew, UK. 
(established under the aegis of the British Royal Society) formed a committee headed by Herschel, Humphrey Lloyd and Edward Sabine, who co-ordinated efforts to establish observatories at Dublin, Hobart, Toronto, St Helena, the Cape of Good Hope, India and Singapore during the 1840s. The primary goal of this massive global operation was to advance 'the science of terrestrial magnetism' but an essential element of this undertaking was meteorological observation, especially the sub-daily recording of atmospheric pressure, the temperature of the earth and of the air (Report, [9-11]).

Some of the observatories were disbanded after 1845, but the practice of taking regular instrumental observations of weather variables by colonial officials in Southeast Asia was by now well established. In the British Straits Settlements, for example, regular daily to sub-daily observations of variables such as air temperature, precipitation and pressure were taken in Penang, Singapore and Malacca from the 1830s, the number of observation stations increasing to twenty-nine by 1885 . There are surviving sub-daily weather observations from Sarawak, East Malaysia during the 1840s, taken by Lieut. Charles Elliot of the Madras Engineers (Singapore, 1841-1845), and records from Indonesia for the 1840s and 1850s (Buitenzorg/Bogor, 1841-1855; Padang, 1850-1853; Batavia/Jakarta, from 1859). For the rest of Southeast Asia, knowledge of instrumental sub-daily weather observations is more erratic but early records have been found by ACRE and its partners for terrestrial Myanmar (Rangoon, 1852-1853); Philippines (Manila from 1884); Thailand (Bangkok, 1858-1868); Vietnam (Ho Chi Minh, 1868); South Korea (1888); Cambodia (Phnom Penh, 1899-1905), and East Timor (from 1914). ${ }^{\mathrm{e}}$ In Asia more broadly, historical instrumental weather observations have so far been found to survive for Canton (1831-1839); Hong Kong (from 1853); Peking/Beijing (from 1841); Macau (for 1835); India (Calcutta, 1784-1786); Madras, (from 1787), and Bombay (from 1816). On the marine side, recovered observations have a long timeframe. British Royal Navy and merchant navy vessels sailed through Southeast Asian waters and their observations are now being researched as part of the ACRE China and ACRE SEA initiatives. For example, Remark's Books (kept by a ship's captain or master) from various marine surveys conducted in Southeast Asian waters are available via ACRE from the 1840s onwards (http://www.met-acre.org/ wg1-data/imaging-and-digitisation-ofhistorical-instrumentalweather-observations-in-ship-logbooks/Report_UKHO_ Remarks_books_inventory_cward_fwilliamson.doc? attredirects $=0$ ).

Such data have been recovered by ACRE and ACRE SEA alongside other data recovery organisations and projects working in the region, including The INdian Ocean DAta REscue (INDARE) project and International
Environmental Data Rescue Organization (IEDRO). Most recently, ACRE SEA has been engaged in extending its network of regional recovery organisations in order to bring together the diverse projects working with similar remits in the area. One of the ways it has achieved this has been by organising an international workshop and also by making contact with, and visiting, regional NMHS. The following section outlines these activities in more detail.

\section{The ACRE SEA project as an umbrella for regional data recovery efforts}

ACRE SEA's first challenge after beginning work formally in 2013, was to arrange the official project launch: a workshop held in Kuala Lumpur during May 2014. The workshop was funded directly by the Asia Pacific Network for Global Change Research under its CAPaBLE scheme. The aims of the workshop were to bring together participants of NMHS, archives and institutions from around the region to discuss and share current data recovery efforts where they exist, and to highlight the significance and uses of historical and documentary data recovery to those participating institutions where such efforts are not currently undertaken for early datasets. In particular, the themes of the workshop sought to emphasise how the process of imaging and digitisation of early instrumental data not only preserves an invaluable, fragile and endangered resource but enables these data to be accessible and usable, both regionally and internationally. The workshop was held in conjunction with the International ASEAN SACA\&D Conference and Workshop 2014 (IASCW-2014) Past, Present and Future; a Display of Climate Science and Services in South East Asia (BMKG-KNMI) held in Indonesia, a decision that enabled delegates to move between both workshops and thus increase opportunities for discussion and data-sharing.

Participants at the workshops hailed from NMHS, archives and universities in Australia, China, Holland, Hong Kong, Indonesia, Japan, Malaysia, Myanmar, New Zealand, Singapore, South Korea, Thailand, Timor-Leste, the United Kingdom, the United States, and Vietnam, and comprised historians, scientists and archivists. The purpose of bringing representatives of the humanities and the sciences together in this way was in sharing information across disciplines and between people who would not normally meet on single disciplinary conference circuits. The workshop resulted in the formation of a multi-disciplinary steering committee to drive future data recovery efforts under the ACRE SEA umbrella.

Over the next year, these efforts will involve connecting with regional NMHS and archives in Thailand, Vietnam, and the Republic of Korea at a series of regional meetings. The purpose of these visits is to build on 
relationships developed during the workshop in order to encourage data recovery, research and sharing. In addition, monies have come to ACRE SEA through an award to ACRE China via the UK BIS Newton Fund which supports research activities between the UK Meteorological Office and the China Meteorological Administration/Beijing Climate Center. These monies will enable capacity building visits to Macau, Cambodia, and Laos, and are supported by ACREs agreement with WMO to boost regional capacities for data sharing and research, and to enhance dialogue on data rescue issues with the relevant NMHS in those countries. Where possible, ACRE SEA seeks to enlist the cooperation and support of regional NMHS to source, catalogue, image, digitise and share all uncovered materials. Where NMHS are willing to cooperate but lack the funds to participate fully, ACRE SEA seeks to find and make available monies for digitisation from external funding. Current funding from the Asia Pacific Network for Global Change Research under its CAPaBLE scheme, for example, includes monies dedicated to digitization as a critical part of the award. ACRE SEA is also currently engaged in seeking future funding opportunities with the digitization component as a core element alongside research and capacity building activities, which will be partly achieved by working closely with the INDARE project to secure Global Framework for Climate Services (GFCS) funding for collaborations with NMHS in the Asian region. In addition, the main ACRE initiative facilitates the digitisation of recovered data through skilled digitisation technicians linked to the Met Office Hadley Centre in the UK and the University of Giessen, Germany.

ACRE SEA regional visits will also involve research at regional archives to scope potential new sources of data and to build a database of all known sources of information, their extent, condition, level of access, and digitisation status. By the end of the funded period, this database will be made available to the public on the main ACRE website (http://www.met-acre.org/data-projectsand-regional-chapters/acre-se-asia).

As has already been mentioned, ACRE SEA does not operate alone in the region but seeks to connect and work with existing data recovery projects and initiatives in Southeast Asian countries in order to improve knowledge sharing and datasets. Members of ACRE SEA represent some of these projects and undertake research in the field. In this way, ACRE SEA acts as an umbrella organisation linking schemes which may currently operate in isolation in order to encourage data sharing. The next section considers some of the work currently being carried out by researchers and scientists connected to ACRE SEA, as well as some of the data recovery research represented at the 2014 ACRE SEA workshop.
Integrated research approaches: documentary evidence and proxy-based reconstructions of natural hazards

By linking its activities and membership with other data recovery initiatives in the region ACRE SEA can benefit from, and assist with, enhancing data recovery efforts. Proxy-based reconstruction as a method of data recovery for assessing extreme weather events has been particularly prominent in the work and interests of the diverse organisations that ACRE SEA connects with. One of the main sources of data used by ACRE SEA are historic records but in many places on earth, the written record of extreme hydrodynamic and natural hazard events is too short or inconsistent to accurately assess the hazard posed by such events on scales beyond those of the average human lifespan [12]. Inconsistency results from the loss of written records, perhaps from natural disaster, insufficient preservation techniques, or simply disinterest. Another problem affecting developing countries in particular is recurrent warfare that has disrupted the making and keeping of weather records. Thus it has been increasingly recognised that the value of written observational records can be greatly extended by placing them in context with other forms of long-term records. Recently there has been a surge of interest in an integrated research paradigm that incorporates instrumental, historical, archaeological and geological records to extend the record of and generate multi-century analyses of the extreme event recurrence intervals, for instance, thus, improving long-term risk assessment (see Figure 1). The premise of integration underpins ACRE and ACRE SEAs operations. Some examples are considered below.

\section{a) Integrating proxy-based reconstructions for tropical cyclones}

The principal obstacle for assessing tropical cyclone hazard (and many others), for example, is the shortness of the historical/instrumental event record (over a few decades up to a couple hundred years). The combined analysis of modern, historical and geological records has recently emerged as a promising tool for reconstructing long-term hazard recurrence intervals and a key step in assessing future risk (e.g. [12,13]). One method commonly appropriated within this framework is paleotempestology, which involves identifying and dating the depositional record left behind by storm induced flooding of coastal environments [14] usually associated with tropical cyclones. Paleotempestology primarily involves the analysis of sandy wash over deposits e.g. [13,15-17] however recent isotopic variation reflected in the chemistry speleothems e.g. $[18,19]$ and tree rings $[20]$ along with boulder and reef clasts on shorelines e.g. [21] have expanded proxy datasets, allowing researchers to estimate the frequency of intense cyclone strikes at a site and assess variability over thousands of years (see 
summary of [13]). Collectively a regional assessment of different sites then allows an investigation of cycloneclimate relationships. Recent examples from the USA (e.g. [22,23], Australia [19] and southern China (see section $\mathrm{b}$ ) have identified relatively active and inactive intervals of cyclone activity, with coincident variability in climate state. It should be noted however that the interpretation of these findings is not straight forward, indeed [13] noted that the direct comparison of modern and prehistoric activity remains difficult.

As frequencies and return times estimated in palaeotempestology commonly yield recurrence intervals on centennial to millennial time scales, they provide an important and overlapping bridge between modern datasets and millennial records from geophysical archives. Recent work on extending records through historical and geophysical archives, allowed comparisons with millennial time scale (assuming stationary climate) numerical simulations and modelling, where risk models extrapolate beyond the historical records e.g. statistical-deterministic hurricane risk model e.g. [24-29].

For most of Southeast Asia (the exceptions being China and Japan [30]) the time scale for which easily accessible, accurate meteorological observations are available is rarely longer than a century, making it difficult to constrain the regional distribution typhoon characteristics. In a recent example a tropical cyclone risk model was integrated with hydrodynamic models to form a climatological-hydrodynamic method to estimate local surge risk in New York City [31,32]. Such approaches could also be applied to Asian cities where detailed records exist (e.g. Hong Kong and Manila). The ACRE SEA project described here has the potential to provide much of the atmospheric and oceanic data required to apply the climatological-hydrodynamic method and give estimates of surge activity on millennial time scales.

\section{b) Reconstruction of historical cyclone activity in the northwest pacific}

Several studies have recently been conducted using historic governmental records in combination with proxy records for this region. Because tropical cyclones spend most of their lifetimes over the ocean, getting historical information on where and when they occurred is difficult unless there were ships in the vicinity that happened to record the event and pass this information to authorities at port. Likewise, cyclones might be noted when they made landfall, for their own sake, or because they caused damage either directly, or as a result of flooding. Kubota and Chan [33] examined the Monthly Bulletins of the Philippine Weather Bureau for the period 19021939 that contained tracks of typhoons that affected the Philippines, and found that the annual number of typhoons that made landfall in the Philippines has no discernible trend but there is a multi-decadal oscillation with an apparent period of about 32 years. Although such a period cannot be statistically determined because of the relative short length of the data, it is consistent with the results using modern-day data [34]. The interdecadal variability appears to be related to the different phases of the El Niño/Southern Oscillation (ENSO) and the Pacific Decadal Oscillation (PDO). During the low PDO phase, the annual landfall number decreases (increases) significantly in El Niño (La Niña) years. During high PDO phase, however, the difference in this annual number between different ENSO phases becomes unclear [33]. Potentials exist to employ the methods that Diamond et al. [35] used in the Southwest Pacific, where they examined 20CR and a coupled ENSO index (CEI) to investigate tropical cyclone genesis areas and climate diagnostics, to typhoons in the South East Asian region.

Southern China has some of the longest and most complete records in the region. In a different study, Chan and Shi [36] examined government records over 22 cities/counties in the Guangdong Province of China during the period 1470-1931 and found that the frequency of typhoon landfall has a positive linear trend, as well as centennial and decadal oscillations. It should be emphasised that such a trend could simply be a reflection of the increased data availability and is not necessarily physical. Similar oscillations in the annual number of typhoons that affected the East China coastal areas, including those in the provinces of Fujian, Zhejiang and Jiangsu for the period 1450-1949, were also obtained when Chan et al. [37] analysed government records from these provinces. By classifying the years using proxy records of the ENSO and PDO phenomena, the annual number of typhoon landfall was found to vary with the different phases of these two prominent oscillations, and such variations can be explained to a large extent by physically based processes in modern-day atmospheric data.

With the variations of typhoon activity in China during the last 500 years relatively well documented, the potential for ACRE SEA to provide an archive of historical records in other countries in Asia (e.g. Japan, Korea, Vietnam, Philippines) is clear and such an analysis would provide a much more comprehensive picture of what has happened during the last 500 years. ACRE is already involved in a general push to digitise terrestrial and marine weather observations made during historical tropical storms, hurricanes and typhoons from the published sources it has found and recovered. Such knowledge is especially important in understanding the computer model projections of typhoon activity in the 21st century under various global warming scenarios. 


\section{c) Proxy-based reconstructions: paleoclimate and records of extreme floods}

Another example of an integrated approach to data recovery concerns flood records. In fluvial systems, evidence has suggested that extreme floods are increasing in Asia along with human vulnerability [38]. In a similar sense to tropical cyclone analysis, the gauged records of floods in Asian rivers are too short to test for stationarity (i.e. randomness or non-randomness), or to determine realistic return periods, to analyze climatological controls that may have long-term trends, and to detect the largest floods that a river catchment can produce. Gauged records therefore need to be supplemented by other evidence of floods to produce long histories. In river systems the palaeoflood records are primarily based on the sediments left by floods [39] and dated by radiocarbon and/or Optically Stimulated Luminescence, documentary evidence, and oral histories. There have been many palaeoflood analyses worldwide [40] but only two studies specific to Southeast Asia [41,42]. Thus it is necessary to draw precedent from studies completed in other countries, and also to recognize the value of extending current research in the region, some of which is already taking place on the Ping River in Thailand.

By way of example, in monsoonal North Australia gauged flood frequency varies with average river discharge and therefore precipitation [43]. Flood frequency based on dated flood sediments has been high since about $1850 \mathrm{CE}$ when average stream flow was high, and flood frequency and discharge were low during the Little Ice Age (LIA). There were no large floods during the Medieval Climate Anomaly (MCA) when discharge was high, a relationship that has yet to be resolved. The frequency series is also non-random.

In the Central Himalayan region, Wasson et al. [44] showed from dated flood sediments that over the past millennium large flood frequency was relatively high during the MCA, low during the LIA, and increased dramatically in the past 200 years, a record that is similar to that in Peninsular India [45]. The Himalayan record is non-random just as in North Australia, violating the key assumption of stationarity that underpins most flood forecasts. In addition there was a cluster of large floods in the Himalayas in the late $18^{\text {th }}$ Century which occurred when the Arctic Oscillation (AO) was strongly negative [46], as it was for the large floods of 1970CE (unpublished result) and 2013CE [47]. The relationship between the $\mathrm{AO}$, the monsoon, and floods in India deserves more investigation.

These results show that long records of flood frequency can be used to test for stationarity and better determine the role of climatological controls of floods. The research currently underway in Thailand has also revealed extreme floods that changed the configuration of the Ping River, and have no equal in the gauged record: one between 1477 and 1512CE [42] and another most likely in 1831CE. ACRE SEA recovered observational weather data for times of significant floods can enhance our understanding of these events in the past.

\section{d) Tree-ring datasets}

The data coverage of tree-ring based paleoclimatic reconstructions across Southeast Asia has improved considerably in recent years. Historically, the generation of tree-ring records for the tropics has lagged considerably behind temperate to higher latitude regions of the globe, due to the fact that many tropical tree species (as a result of decreased temperature seasonality near the equator), do not form well-defined annual growth rings. However, in recent decades it has been found that the wood of certain tree species, mainly of old growth conifers as well as teak (Tectona grandis), respond to fluctuations in the dry and wet seasons associated with the Asian monsoon, and consequently can be absolutely cross-dated and used to develop annually-resolved treering chronologies. Notably, a long-term project at the Lamont-Doherty Earth Observatory's Tree-Ring Laboratory (TRL-LDEO) focused on the generation of an extensive tree-ring dataset for monsoon Asia, entitled the Monsoon Asia Drought Atlas or MADA, spanning much of the past millennium. More than sixty publications have resulted from the MADA project to date (examples include: [48-51]. TRL-LDEO scientists developed and continue to use this network to reconstruct tropical Indo-Pacific hydroclimate, sea surface temperatures (SSTs), and spatial field patterns of drought indices for the past millennium (e.g., [51-53]). This project has linked monsoon variability to past societal upheavals from China to Indochina and India (e.g. [48]). Asian scientists/students visited LDEO for training workshops under this project, and tree-ring labs were established in many Asian countries. The MADA is now available to the public, and could potentially be used as a valuable data resource for comparison to and validation of the historical records generated by ACRE SEA. MADA documented data have not yet been reproduced by $20 \mathrm{CR}$ but the overlapping timeframe of MADA data with 20CR make this a possibility for the future (for similar examples see [54]).

The examples above are all positive demonstrations of some of the regional work currently being undertaken with links to ACRE SEA, and the potential for ACRE SEA recovered data to be integrated with proxyreconstructions following recent research trends. These examples also reveal some of the varied uses of ACRE SEA recovered data for the wider scientific community. One important consideration that has not yet been addressed however, is how to catalogue, assimilate and 
store the large quantities of data generated during these, and similar, projects especially given the variety of sources and different data formats presented. ACRE is currently engaged in compiling all known information into databases but more significantly, is working with WMO on finding a permanent solution for public accessibility. This is taking the form of a proposal for an international data portal which is being discussed and developed under the WMO Commission for Climatology's Expert Team on Data Rescue (ET-DARE). Some serious concerns also remain with regard to making recovered data comprehensible to a wide audience and made available publically. In many Southeast Asian countries, Malaysia and Thailand for example, recovered data is considered the property of the respective government to which the data relates and it has thus far not been possible to make it available publically. For now, only data available in Europe (usually held by former colonial governments) for Southeast Asian countries has been made public.

\section{Cataloguing, databases, digitization and public availability}

To store, archive and make available this large and heterogeneous collection of data requires the careful implementation of established principles of digital curation. In particular, the project's overriding aim to make its collected data freely available to scientific communities requires the application of standard practices and methodologies to its ingestion, archival storage and the way in which it is disseminated. These need to cover all aspects of the curation process, including the choice of formats for data storage, the metadata needed to support it, and the way in which the systems used for archiving and delivery are being designed.
The diagram below (Figure 3), is a representation of the widely-used OAIS (Open Archival Information System) model for designing and implementing digital archives, and it illustrates the key components of a working archive which require the application of carefully chosen standards and practices (Consultative Committee for Space Data Systems, [55], p. 4-1). In particular it demonstrates the three different forms which the archive's data and metadata need to take (the Submission Information Package (SIP), Archival Information Package (AIP) and Dissemination Information Package (DIP)) as they move from ingestion to storage to delivery to users. As can be seen from Figure 3 below, the archival storage of data is only a small part of this range of functions and actions.

Using a scheme of this kind as a 'check-list' for an archive, ensures that it can be trusted as a repository for the valuable data that is collected. For each component within this diagram, established standards exist for formats, practices and methodologies which allow high levels of interoperability of data and its robust long-term preservation. Applying these ensures that the most basic functions of data curation can be safely managed.

From this assembled data, the reanalyses and visualisations which enrich the data as disseminated can be built. To enable the use of these data in a global information environment requires the use of interoperable metadata standards, carefully chosen to capture the full complexity of the data without consigning it to 'silos' which cannot communicate beyond themselves. Semantic web ontologies have already been recognised (for instance by Emile-Geay and Eshleman [56]) as potential enablers of interoperability for paleoclimate data. Further work will be required to devise ontologies of this type and integrate them with pre-existing metadata standards.

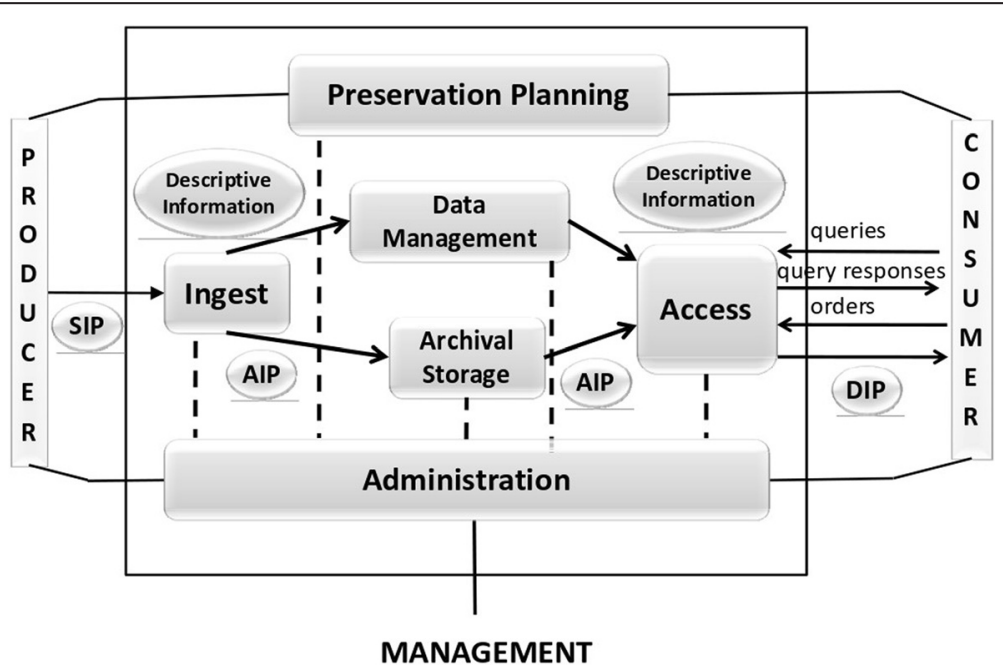

Figure 3 "OAIS (Open Archival Information System) conceptual model for data archives" (from Consultative Committee for Space Data Systems, 2012, p.4-1). 
One of the "datasets" that can be used to enhance our knowledge of the spatial distribution of weather variables is the ACRE-facilitated $20^{\text {th }}$ Century Reanalysis (20CR) that gives spatially and temporally-complete 4D historical global weather variables, and can be downscaled for use over the SE Asian region. The 20CR reanalysis currently covers the period 1871-2012 (http://www.esrl.noaa.gov/ psd/data/20thC_Rean/), and is generated using the weather observations that ACRE and other initiatives and projects recover. It provides the first-ever estimates of long historical near-surface to tropopause level 6-hourly fields of weather variables and derived quantities (e.g., storm tracks) extending back into the $19^{\text {th }}$ Century plus additional estimates of uncertainties, via a 56 member ensemble of realizations at each 6-hourly time step.

As with all reanalyses, 20CR seeks to be tested and checked for its veracity, and is only as good as the quality of the Numerical Weather Prediction (NWP) model and parameterizations at the heart of it, and the quality and quantity of the data being assimilated into it. Full quality controls are applied to all of the data being fed into 20CR, but its system also generates an error/uncertainty field for each variable using the 56 realisations at each time step and level in the atmosphere. Examinations of these uncertainty fields, post process, can also help to establish the nature and extent of many data errors or problems arising, and allow for efforts to correct them before such data are assimilated into reruns of 20CR.

In this discussion however, and despite WMO Resolution 40 (http://www.wmo.int/pages/about/Resolution40_en.html), securing the agreement of regional NMHSs in making data freely available can still be a problem. In most countries, data resides under the protection of governmental bodies (NMHS or a national archive) and as such, is covered by data protection laws. Even where data is held within a public archive, the ability to make this data available, say online, is restricted. In many cases, securing permissions to use data can stall the process of imaging, digitisation and thus reanalysis and thus the realisation of the full potential of ACRE SEA is only possible with the full cooperation and agreement of participating countries.

\section{Conclusions}

It is clear that ACRE SEA has great potential to recover regional weather, climate and environmental data for imaging, digitisation and, ultimately, use in new state-ofthe art reanalyses. It is both conducting its own research on a country-to-country basis, and looking to connect with other regional data recovery projects in joint activities across Southeast Asia. Importantly, it has, as its prime aim, the key question of the integration of instrumental with documentary, proxy and archeological records for the benefit of all.

The ability of ACRE SEA to cross inter-disciplinary boundaries and connect wider social and humanities research activities and findings with proxy-based weather reconstructions, reveals the versatility and considerable uniqueness of this initiative in Southeast Asia. Many problems remain to be tackled however, not least the sourcing of records for developing countries where observations are recent and partial, or hard to recover. To lessen and negotiate such constrictions to positive conclusions for all parties, ACRE SEA is working closely with WMO and other international bodies which regularly interact with the various countries and NHMS in Southeast Asia. It is hoped that with WMO support and direction from the newly established steering group, ACRE SEA will be enabled to grow and improve data recovery capacities over the coming years.

\section{Endnotes}

${ }^{\mathrm{a}} \mathrm{ACRE}$ is supported by a core consortium of nine international partners: University of Southern Queensland, Australia; the US National Oceanic and Atmospheric Administraon (NOAA) Earth System Research Laboratory (ESRL) and Cooperative Institute for Research in Environmental Sciences (CIRES) at the University of Colorado; The National Climatic Data Center (NCDC) of NOAA; the International Environmental Data Rescue Organization (IEDRO); the University of Sussex, UK, the British Library, UK; the University of Giessen, Germany and the University of Bern, Switzerland.

${ }^{\mathrm{b}}$ For more information on this see: [57] Assessment of long historical reanalyses for use in monitoring and attribution and model validation - ACRE-facilitated 20CR and EU FP7 ERA-CLIM/ERA-CLIM2 reanalyses outputs. Underpinning Science Internal Met Office Deliverable, MOHC - DECC \& Defra (GA01101) 2012-2015, 50 pp. (https://docs.google.com/viewer?a=v\&pid=sites\&srcid= bWVOLWFjcmUub3JnfGFjcmV8Z3g6MWEwMTRjMz IOZmE0ZTEwNg).

${ }^{\mathrm{c}}$ Disproving popular belief that pre-1790s observational data is unreliable at best, recent research has argued that even before the invention of the chronometer, observations had a high level of accuracy and can be used - with certain provisos - by modern day scientists. For more on this see: [58] CLIWOC, Climatological Database for the World's Oceans 17501850 EU Publication Office: Ch. 1 \& 6 or [59] CLIWOC, Climatological Database for the World's Oceans 1750-1850 Climatic Change 73 (1-2): 1-12.

${ }^{\mathrm{d}}$ For the report see: https://sites.google.com/a/met-acre. org/acre/wg1-data/1839MEMORANDUM.TIF.

${ }^{\mathrm{e}}$ For Rangoon see International Surface Pressure Data (ISPD), Station Report 1877-1940 available at UK 
Meteorological Office Archive (UKMO); Manila: China Coast Meteorological Register (CCMR) 1873-1891; Bangkok 1858-1868: http://badc.nerc.ac.uk/browse/badc/ corral/images/metobs/asia/Thailand/Bangkok_1858-1868; Vietnam: courtesy of Vietnam Meteorological Service; Phnom Penh: some data is available in CISL RDA ds570.0, other is available online in Bulletin économique de l'IndoChine on Gallica Bibliothèque Numérique's website, e.g. http://gallica.bnf.fr/searchInPeriodique?spe=meteorologiques $\% 2 \mathrm{C}+$ Indochine+francaise\&arkPress $=\mathrm{cb} 32728645$ t $\% 2$ Fdate\& lang=EN; Weather data in Timor Leste: An Overview of Sources of Weather Data for Timor Leste, Report compiled by Seeds of Life (2014).

\begin{abstract}
Abbreviations
(AO): Arctic Oscillation; (ACRE): Atmospheric Circulation Reconstructions over the Earth; (BMKG): Indonesian Agency for Meteorology, Climatology and Geophysics; (CRU): Climatic Research Unit; (CIRES): Cooperative Institute for Research in Environmental Sciences; (ENSO): El Niño/Southern Oscillation; (EEIC): English East India Company; (ESRL): Earth System Research Laboratory; (ERA-CLIM2): EU FP7 European Reananlysis of the Global Climate System; (GFCS): Global Framework for Climate Services; (GPCC): Global Precipitation Climatology Centre; (GLOSS): Global Sea Level Observing System; (INDARE): Indian Ocean Data Rescue Initiative; (IEDRO): International Environmental Data Rescue Organization; (ISPD): International Surface Pressure Data; (ISTI): International Surface Temperature Initiative; (TRLLDEO): Lamont-Doherty Earth Observatory's Tree-Ring Laboratory; (LIA): Little Ice Age; (MCA): Medieval Climate Anomaly; (MADA): Monsoon Asia Drought Atlas; (MOHC): Met Office Hadley Centre; (NCDC): National Climatic Data Center; (NMHS): National Meteorological and Hydrological Services; (NOAA): National Oceanic and Atmospheric Administration; (PDO): Pacific Decadal Oscillation; (KNMI): Royal Netherlands Meteorological Institute; (SST): Sea surface temperature; (WMO): World Meteorological Organization; (ET-DARE): WMO Commission for Climatology's Expert Team on Data Rescue.
\end{abstract}

\section{Competing interests}

The authors declare that they have no competing interests.

\section{Authors' contributions}

All authors cited above helped to draft the manuscript. All authors read and approved the final manuscript. FW coordinated the collation of individual contributions, and FW and RA edited the final manuscript.

\section{Acknowledgements}

We would like to thank the Asia-Pacific Network for Global Change Research and the CAPaBLE Programme for Scientific Development for helping to make Atmospheric Circulation Reconstructions over the Earth: Southeast Asia regional project possible with funding for 2013-15

\begin{abstract}
Author details
${ }^{1}$ School of History, Politics and Strategy, Faculty of Social Sciences and Humanities, National University of Malaysia, Selangor 43600, Malaysia. ${ }^{2}$ International ACRE Initiative Manager, Met Office Hadley Centre, ExeterEX1 3PBUK. ${ }^{3}$ Singapore NRF Fellow, Nanyang Assistant Professor, Division of Earth Sciences and Principal Investigator, Earth Observatory of Singapore, Nanyang Technological University N2-01C-39, 50 Nanyang Avenue, Singapore 639798, Singapore. ${ }^{4}$ Guy Carpenter Asia-Pacific Climate Impact Centre, School of Energy and Environment, City University of Hong Kong, Tat Chee Avenue, Kowloon, Hong Kong SAR. Institute of Water Policy, Lee Kuan Yew School of Public Policy National University of Singapore, 469C Bukit Timah Road, Level 2, Wing A Singapore 259772, Singapore. ' 'Lamont Research Professor, Tree-Ring Laboratory, Lamont-Doherty Earth Observatory, Palisades, New York, USA. 'Department of Digital Humanities, King's College London, Centre for e-Research, 26-29 Drury Lane, King's College London, LondonWC2B 5RLUK.
\end{abstract}

Received: 18 October 2014 Accepted: 9 January 2015

Published online: 27 February 2015

\section{References}

1. Lamb HH (1977) Climate: Present, Past and Future. Vol. 2: Climatic History and the Future. Methuen, London

2. Le Roy Ladurie E (1972) Times of Feast, Times of Famine: A History of Climate since the year 1000. Doubleday, New Jersey

3. Allan R, Brohan P, Compo GP, Stone R, Luterbacher J, Brönnimann S (2011) The International Atmospheric Circulation Reconstructions over the Earth (ACRE) initiative. Bull Amer Met Soc 92:1421-1425, doi:10.1175/ 2011BAMS3218.1

4. Stickler A, Brönnimann S, Valente MA, Bethke J, Sterin A, Jourdain S, Roucaute E, Vasquez MV, Reyes DA, Guzman JG, Allan RJ, Dee D (2014) ERA-CLIM: Historical Surface and Upper-Air Data for Future Reanalyses. Bull Amer Met Soc 95(9):1419-1430, http://dx.doi.org/10.1175/BAMS-D-13-00147.1

5. Brönnimann S, Martius $O$ (2013) Weather extremes during the past 140 years. Geographica Bernensia G89:108, doi:10.4480/GB2013.G89.05

6. Brohan P, Allan R, Freeman E, Wheeler D, Wilkinson C, Williamson F (2012) Constraining the temperature history of the past millennium using early instrumental observations. Climate of the Past J 8:1653-1685

7. Golinski J (2007) British Weather and the Climate of Enlightenment. Chicago University Press, Chicago

8. Anderson K (2010) Predicting the Weather: Victorians and the Science of Meteorology. University of Chicago Press, Chicago

9. Report of the Tenth Meeting of the British Association for the Advancement of Science, 1840. London: J. Murray.

10. Report of the Fifteenth Meeting of the British Association for the Advancement of Science, 1845. London: J. Murray.

11. Report of the Twenty-Fourth Meeting of the British Association for the Advancement of Science, 1854. London: J. Murray.

12. Switzer AD, Yu F, Gouramanis C, Soria JLA, Pham DT (2014) Integrating different records to assess coastal hazards at multi-century timescales. J Coastal Res SI 70:122-129

13. Lin N, Lane P, Emanuel KA, Sullivan RM, Donnelly JP (2014) Heightened hurricane surge risk in northwest Florida revealed from climatologicalhydrodynamic modeling and paleorecord reconstruction. J Geophysical Res: Atmospheres 119(14):8606-8623

14. Nott J (2004) Palaeotempestology: the study of prehistoric tropical cyclones-a review and implications for hazard assessment. Environ Int 30(3):433-447

15. Donnelly JP, Bryant SS, Butler J, Dowling J, Fan L, Hausmann N, Webb T (2001) 700 yr sedimentary record of intense hurricane landfalls in southern New England. Geol Soc Am Bull 113(6):714-727

16. Donnelly JP, Woodruff JD (2007) Intense hurricane activity over the past 5,000 years controlled by El Nino and the West African monsoon. Nature 447(7143):465-468

17. Liu KB, Fearn ML (2000) Reconstruction of prehistoric landfall frequencies of catastrophic hurricanes in northwestern Florida from lake sediment records. Quatern Res 54(2):238-245

18. Frappier AB, Sahagian D, Carpenter SJ, González LA, Frappier BR (2007) Stalagmite stable isotope record of recent tropical cyclone events. Geology 35(2):111-114

19. Haig J, Nott J, Reichart GJ (2014) Australian tropical cyclone activity lower than at any time over the past 550-1,500 years. Nature 505(7485):667-671

20. Miller DL, Mora Cl, Grissino-Mayer HD, Mock CJ, Uhle ME, Sharp Z (2006) Tree-ring isotope records of tropical cyclone activity. Proc Natl Acad Sci 103 (39):14294-14297

21. Terry JP, Etienne S (2014) Potential for timing high-energy marine inundation events in the recent geological past through age-dating of reef boulders in Fiji. Geoscience Letters 1(1):1-8

22. Lane P, Donnelly JP, Woodruff JD, Hawkes AD (2011) A decadally-resolved paleohurricane record archived in the late Holocene sediments of a Florida sinkhole. Mar Geol 287(1-4):14-30

23. Mann ME, Woodruff JD, Donnelly JP, Zhang Z (2009) Atlantic hurricanes and climate over the past 1,500 years. Nature 460(7257):880-883

24. Emanuel K, Ravela S, Vivant E, Risi C (2006) A statistical deterministic approach to hurricane risk assessment. Bull Am Meteorol Soc 87(3):299-314

25. Hall TM, Jewson S (2007) Statistical modelling of North Atlantic tropical cyclone tracks. Tellus A 59(4):486-498

26. Resio DT, Irish J, Cialone M (2009) A surge response function approach to coastal hazard assessment-part 1: basic concepts. Nat Hazards 51 (1):163-182

27. Scheffner NW, Borgman LE, Mark DJ (1996) Empirical simulation technique based storm surge frequency analyses. J Waterw Port Coast Ocean Eng 122 (2):93-101 
28. Vickery PJ, Skerlj PF, Twisdale LA (2000) Simulation of hurricane risk in the US using empirical track model. J Struct Eng 126(10):1222-1237

29. Toro GR, Resio DT, Divoky D, Niedoroda AW, Reed C (2010) Efficient jointprobability methods for hurricane surge frequency analysis. Ocean Eng 37 (1):125-134

30. Zaiki M, Konnen GP, Tsukahara T, Mikami T, Matsumoto K, Jones PD (2006) Recovery of 19th century Tokyo/Osaka meteorological data in Japan. Int J Clim 26:399-423

31. Lin, N., Emanuel, K. A., Smith, J. A., Vanmarcke, E. (2010) Risk assessment of hurricane storm surge for New York City. Journal of Geophysical Research: Atmospheres (1984-2012), 115(D18).

32. Lin N, Emanuel K, Oppenheimer M, Vanmarcke E (2012) Physically based assessment of hurricane surge threat under climate change. Nature Climate Change 2(6):462-467

33. Kubota H, Chan JCL (2009) Interdecadal variability of tropical cyclone landfall in the Philippines from 1902 to 2005. Geophys Res Lett 36:L12802, doi:10.1029/2009GL038108

34. Chan JCL, Xu M (2009) Interannual and interdecadal variations of landfalling tropical cyclones in East Asia. Part I: Time series analysis. Int'l J Climatol 29:1285-1293

35. Diamond HJ, Lorrey AM, Renwick JA (2013) A Southwest Pacific Tropical Cyclone Climatology and Linkages to the El Niño-Southern Oscillation. J Climate 26:3-25, doi:10.1175/JCLI-D-12-00077.1

36. Chan JCL, Shi JE (2000) Frequency of typhoon landfall over Guangdong province of China during the period 1470-1931. Int'l J Climatol 20:183-190

37. Chan JCL, Liu K-S, Xu M, Yang Q (2012) Variations of frequency of landfalling typhoons in East China, 1450-1949. Int'l J Climatology 32:1946-1950

38. Douglas, M. (2013) The Urban Transition of Environmental Disaster Governance. Asia Research Institute, National University of Singapore, Working Paper Series No. 210, 32pp.

39. Baker VR (1987) Paleoflood hydrology and extraordinary flood events. J Hydrology 96(1):79-99

40. Baker, V. R. (2013) Global late Quaternary fluvial paleohydrology: with special emphasis on paleofloods and megafloods. In: Shroder, J. (Editor in Chief), Wohl, E. (Ed.), Treatise on Geomorphology. Academic Press, San Diego, CA, vol. 9, Fluvial Geomorphology: 511-527

41. Kidson R, Richards KS, Carling PA (2005) Hydraulic model calibration for extreme floods in bedrock-confined channels: case study from northern Thailand. Hydrological Processes 20:329-344

42. Ng S, Wood SH, Ziegler AD (2014). Ancient floods, modern hazards: the Ping River, paleofloods and the 'lost city' of Wiang Kum Kam. Natural Hazards, doi:10.1007/s11069-014-1426-7

43. Wasson RJ, Bayliss P (2010) River flow and climate in the 'top end' of Australia for the last 1000 years, and the Asian-Australian monsoon. In: Winderlich S (ed) Symposium 4: Climate Change. 6-7 August 2008, Gagudju Crocodile Holiday Inn Kakadu National Park. Internal Report 567, January, Supervising Scientist, Darwin, pp 47-56

44. Wasson RJ, Sundriyal YP, Chaudhary S, Manoj K, Jaiswal P, Morthekai SP, Sati Juyal N (2013) A 1000-year history of large floods in the Upper Ganga catchment, central Himalaya, India. Quaternary Sci Reviews 77:156-166

45. Kale V, Baker VR (2006) An extraordinary period of low-magnitude floods coinciding with the Little Ice Age: palaeoflood evidence from Central and Western India. J Geological Soc India 68:477-483

46. Darby DA, Ortiz JD, Grosch CE, Lund SP (2012) 1,500-year cycle in the Arctic Oscillation identified in Holocene Arctic sea-ice drift. Nat Geosci 5:897-900

47. Joseph, S., Sahai, S.A.K., Sharmila, S., Abhilash, S., Borah, N., Chattopadhyay, R., Pillai, P.A., Rajeevan, M., Kumar, A. (2014) North Indian heavy rainfall event during June 2013: diagnostics and extended range prediction. Climate Dynamics doi:10.1007/s00382-014-2291-5

48. Buckley B, Anchukaitis K, Penny D, Fletcher R, Cook E, Sano M, Nam L, Wichienkeeo A, Minh T, Hong T (2010) Climate as a contributing factor in the demise of Angkor, Cambodia. Proc. Nat. Acad. Sci., March 29 doi:10.1073/pnas.0910827107

49. D'Arrigo R, Allan R, Wilson J, Palmer J, Sakulich J, Smerdon S, Bijaksana Ngkoimani $L$ (2008) Pacific and Indian Ocean Climate signals in a tree-ring record of Java monsoon drought. Int. J. Clim. doi:10.1002/joc.1679

50. Ummenhofer C, D'Arrigo R, Anchukaitis K, Buckley B, Cook E (2013) Links between Indo-Pacific climate variability and drought: Monsoon Asia Drought Atlas. Clim Dyn 40:1319-1334
51. Cook E, Anchukaitis K, Buckley B, D'Arrigo R, Wright W, Jacoby G (2010) Asian Monsoon failure and megadrought during the last millennium. Science 328:486-489

52. D'Arrigo R, Palmer J, Ummenhofer CC, Kyaw NN, Krusic P (2013) Myanmar monsoon drought variability inferred by tree rings over the past 300 years: linkages to ENSO. PAGES news 21(2):50-51

53. Zhu M, Stott L, Buckley B, Yoshimura K (2012) 20th century seasonal moisture balance in Southeast Asian montane forests from tree cellulose 8180. Climatic Change, doi:10.1007/s10584-012-0439-z

54. Giese BS, Compo GP, Slowey NC, Sardeshmukh PD, Carton JA, Ray S, Whitaker JS (2010) The 1918/1919 El Niño. Bull Am Meteorol Soc 91:177-183, doi:10.1175/2009BAMS2903

55. Consultative Committee for Space Data Systems (2012). Reference Model for an Open Archival Information System (OAIS). Washington, DC: CCSDS Secretariat

56. Emile-Geay J, Eshleman JA (2012) Towards a semantic web of paleoclimatology. Geochem Geophys Geosyst 14(2):457-469

57. Allan R, Parker D, Rayner N, Compo G (2014) Assessment of long historical reanalyses for use in monitoring and attribution and model validation - ACREfacilitated 20CR and EU FP7 ERA-CLIM/ERA-CLIM2 reanalyses outputs. Underpinning Science Internal Met Office Deliverable, MOHC - DECC \& Defra (GA01101) 2012-2015, 50 pp. (https:/docs.google.com/viewer?a=v\&pid=sites \&srcid=bWVOLWFjcmUub3JnfGFjcmV8Z3g6MWEWMTRjMzI0ZmE0ZTEWNg).

58. Wheeler D, García-Herrera R, Koek F, Wilkinson C, Können G, Prieto MR, Jones PD, Casale R (2006) CLIWOC, Climatological Database for the World's Oceans 1750-1850 EU Publication Office

59. García-Herrera R, Können G, Wheeler D, Prieto MR, Jones PD, Koek F (2005) CLIWOC, Climatological Database for the World's Oceans 1750-1850. Clim Change 73(1-2):1-12

\section{Submit your manuscript to a SpringerOpen ${ }^{\circ}$ journal and benefit from:}

- Convenient online submission

Rigorous peer review

- Immediate publication on acceptance

- Open access: articles freely available online

- High visibility within the field

- Retaining the copyright to your article

Submit your next manuscript at $>$ springeropen.com 